Acta Regionalia et Environmentalica 2

Nitra, Slovaca Universitas Agriculturae Nitriae, 2017, pp. 59-63

\title{
POSSIBILITIES OF SATISFYING THE ENERGY NEEDS OF RURAL COMMUNITY RESIDENTS WITH RENEWABLE ENERGY SOURCES - THE CASE OF POLAND
}

\author{
Anna BERNACIAK ${ }^{*}$, Arnold BERNACIAK ${ }^{2}$, Klaudia ZASADA ${ }^{3}$, Aleksandra LIS ${ }^{3}$ \\ ${ }^{1}$ Poznan University of Economics and Business, Poznań, Poland \\ ${ }^{2}$ WSB University in Poznań, Poland \\ ${ }^{3}$ Adam Mickiewicz University in Poznań, Poland
}

\begin{abstract}
The historical, economic and legal conditions of the Polish energy supply system differ from other European countries. The share of renewable energy sources in the overall energy balance is still limited. The main purpose of this study is to investigate whether it is possible to meet the energy needs of the basic unit of the territorial organization in Poland, i.e. a commune, exclusively from renewable sources. The main emphasis was put on the methods of estimating the demand of the inhabitants of a commune for energy and the possibility of producing it in an alternative way. The presented considerations could be used as a support for decision makers on the regional and local level in Poland and other European countries, who face the same challenges in energy supply.
\end{abstract}

Keywords: rural community; renewable energy sources; energy needs

The role of rural areas in power generation has recently become the subject of interest of researchers (Poggi, Firmino and Amado 2017). What is an important issue, however, is the efficiency of the transmission and use of power rather than the possibilities of energy generation themselves. In Polish conditions, these issues have not been effectively operationalized yet, although their formal and legal framework has been specified in numerous strategic documents and legal acts. On one hand, Poland implements the EU guidelines included in directives, but on the other, a number of economic and social barriers makes it difficult to put them into practice.

The main aim of this paper is to examine, based on the analysis of statistical data and a social survey, whether it is possible to satisfy the energy needs of a rural commune with renewable energy sources.

\section{The formal and legal framework of the renewable energy use in Poland}

The legal framework of the area of energy management, including energy from renewable sources, is provided by two main parliamentary acts. The first of them is the act of 10 April 1997 - the Energy Law (Journal of Laws 2017, item 220, as amended), the other one - the act on renewable energy sources of 20 February 2015 (Journal of Laws 2017, item 1148, as amended). ${ }^{1}$ Both acts implement

1 The act on renewable energy sources has been amended several times since it entered into force in 2015. The latest amendment, signed by the President of the RP on 14 August 2017, introduces significant changes, especially when it comes to the compensatory payment for the manufacturers who signed the so-called Certificate Purchase Agreements (CPA). Among the directives of the European Communities, including the Directive 2009/28/EC of the European Parliament and of the Council of 23 April 2009 on the promotion of the use of energy from renewable sources and amending and subsequently repealing Directives 2001/77/EC and 2003/30/EC (Official Journal of the European Union L 140 of 5 June 2009, as amended) and the Directive 2012/27/EU of the European Parliament and of the Council of 25 October 2012 on energy efficiency, amending Directives 2009/125/ EC and 2010/30/EU and repealing Directives 2004/8/EC and 2006/32/EC (Official Journal of the European Union L 135 of 14 November 2012). ${ }^{2}$ Apart from acts of the legislature, there are a number of executive documents, such as ministerial regulations, and strategic documents. The key strategic documents concerning the prospects and development of the energy market in Poland include:

- the Polish Energy Policy until 2030 (November 10, 2009),

- national Action Plan on Renewable Energy (December 7, 2010),

other important documents we need to mention the new act on energy efficiency of 20 May 2016, repealing the earlier act of 15 April 2011 (Journal of Laws 2016, item 831) implementing the Directive 2012/27/EU of the European Parliament and of the Council of 25 October 2012 on energy efficiency, amending Directives 2009/125/EC and 2010/30/EU and repealing Directives 2004/8/EC and 2006/32/EC (Official Journal of the European Union L 135 of 14 November 2012, p. 1).

2 Detailed regulations concerning the effective implementation of EU energy directives in Poland are discussed in the publication prepared by ClientEarth Poland Foundation, entitled Implementacja prawa klimatyczno-energetycznego UE w Polsce (The Implementation o EU Climate \& Energy Law in Poland 2013). 
- energy Mix 2050. Scenario analysis for Poland. Warsaw 2011 (Ministry of Economy),

- the Energy Mix for Poland until 2060. Warsaw 2013 (The Prime Minister Office, Strategic Analysis Department: The Optimum),

- the strategy of "Energy Security and Environment perspective until 2020" adopted by the Council of Ministers (Szczerbowski and Ceran 2015).

Additionally, local and regional governments adopt and implement strategic documents concerning low emission reduction and the development of the energy market (Graczyk, 2016; Klojzy-Karczmarczyk and Mazurek, 2009; Gradziuk and Gradziuk, 2016; Clap, Briner and Karousakis, 2010).

All these efforts, both in the sphere of legislation and planning and strategy, are aimed to optimize the management of non-renewable energy sources in the process of power generation and to reduce the negative influence of this process on people and environment (Baños et al., 2011). In this process, Poland, like any other country, has to contend with specific challenges related to its previous energy mix - unfavourable to the condition of the environment - in which more than $85 \%$ of energy is obtained from coal, and to changes in law in the sector of renewable energy and to the need for meeting emission standards based on international commitments and agreements (Piria, 2014; Paska and Surma, 2014). These problems are intensified by the issue of limited financial and human resources and social and formal barriers to the "greening" of the energy sector in Poland. ${ }^{3}$

\section{The diagnosis of a demand for energy in a rural commune}

The demand of a commune - the smallest administrative unit - for energy may be estimated in two ways. The first path consists in using the available statistical data gathered on the local, regional and national level. Such data, supplemented by the conversion factors of, for example, the calorific value of different fuels, allow us to assess the commune's demand for energy in quite a precise way. However, they do not include information about the spatial distribution of demand and do not enable us to discover "hidden data" related to the grey economy, informal exchange relations (barter) or residents' actual needs. The other path involves obtaining data through a social survey. ${ }^{4}$ This method is a lot more expensive and more demanding than the first one, but it allows us to gather detailed real data, along with the information related to their spatial distribution. It also makes it possible for us to find "hidden data."

A comprehensive social survey conducted, for example, with the aim of preparing a low carbon emission economy plan, should include three main groups of questions concerning the consumption of energy, the applied sources of energy, and the possibilities and readiness to use energy from renewable sources. As a result, we may obtain a set of data on:

3 See: Also an in-depth comparative study of the selected regions and countries of Europe prepared by Śliż-Szkliniarz (2013).

4 This path may be complementary to the first one or constitute an autonomous foundation for a diagnosis.
1. the amount of total annual/monthly energy consumption (with its spatial dimension, type of source, cost),

2. current energy production,

3. potential energy production.

An in-depth analysis of this data enables us to prepare a diagnosis concerning the demand of the commune's residents for energy and the possibility of satisfying this demand with the use of different resources.

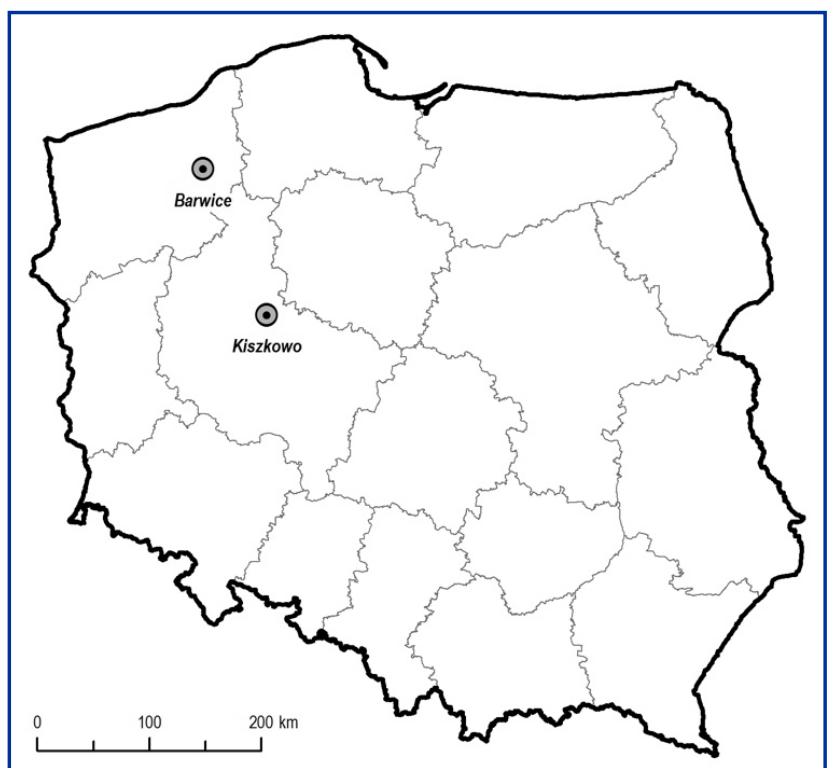

Figure 1. The communes of Barwice (West Pomeranian Province) and Kiszkowo (Greater Poland Province) Source: Author's own work

As an example of the use of survey data for estimating the demand of the commune's inhabitants for electric power, we present the results of the study conducted for two rural communes in Poland - Barwice (located in West Pomeranian Province, in the district of Szczecinek) and Kiszkowo (Greater Poland Province, the district of Gniezno) (Figure 1).

They are both rural communes, with the area of 115 square kilometers - Kiszkowo and 260 square kilometers - Barwice (Table 1). Kiszkowo has higher population density ( 47 people sq $\mathrm{km}^{-1}$ ) than Barwice and has a larger share of agricultural land (88\%) and protected areas (24\%). Barwice, in turn, has more wooded areas (woodland accounts for $35 \%$ of the total area) and is more urbanized.

Table 1 The characteristics of the communes of Kiszkowo and Barwice

\begin{tabular}{|l||c|c|}
\hline Commune & Kiszkowo & Barwice \\
\hline Total area $\left(\mathbf{k m}^{\mathbf{2}}\right.$ ) & 114.6 & 259 \\
\hline Population (person) & 5414 & 8710 \\
\hline Population density (pers. $\mathbf{k m}^{-2}$ ) & 47 & 34 \\
\hline Woodland (\%) & 8.7 & 35.4 \\
\hline Agriculture (\%) & 88 & 47 \\
\hline Protected areas (\%) & 24 & 11 \\
\hline
\end{tabular}

Source: Author's own work 
Table 2 The total annual consumption of thermal energy in the commune of Kiszkowo

\begin{tabular}{|c|c|c|c|c|c|c|}
\hline \multirow[t]{2}{*}{ Fuel type } & \multirow[t]{2}{*}{ Calorific value } & \multirow[t]{2}{*}{ Unit } & \multicolumn{2}{|c|}{ Total consumption } & \multirow{2}{*}{$\begin{array}{l}\text { Total consumption } \\
\text { (MJ) }\end{array}$} & \multirow{2}{*}{$\begin{array}{c}\text { Total consumption } \\
\text { (kWh) }\end{array}$} \\
\hline & & & kg & $\mathrm{m}^{3}$ & & \\
\hline Hard coal & 22.61 & $\mathrm{MJ} \mathrm{kg}^{-1}$ & $509,007.30$ & - & $11,508,655.1$ & $3,196,565.8$ \\
\hline Lignite & 8.29 & $\mathrm{MJ} \mathrm{kg}^{-1}$ & $20,290.91$ & - & $168,211.6$ & $46,466.2$ \\
\hline Gas & 48.00 & $\mathrm{MJ} \mathrm{m}^{-3}$ & - & $19,998.30$ & $959,918.4$ & $266,577.3$ \\
\hline LPG & 47.30 & $\mathrm{MJ} \mathrm{m}^{-3}$ & - & $1,419.13$ & $67,124.8$ & $18,647.4$ \\
\hline Firewood & 15.60 & $\mathrm{MJ} \mathrm{kg}^{-1}$ & $3,206,478.80$ & - & $50,021,069.3$ & $13,884,053.2$ \\
\hline \multicolumn{5}{|l|}{ Total } & $62,724,979.2$ & $17,412,309.9$ \\
\hline
\end{tabular}

Table 3 The total annual consumption of energy in households in the commune of Kiszkowo

\begin{tabular}{|c|c|c|}
\hline Electricity consumption (MWh) & Heat energy consumption (MWh) & Total energy consumption (MWh) \\
\hline \hline $3,699.8$ & $17,412.3$ & $21,112.13$ \\
\hline \multicolumn{2}{|c}{ Source: Author's own work }
\end{tabular}

Table 4 The total annual consumption of energy in households in the commune of Barwice

\begin{tabular}{|c|c|c|}
\hline Electricity consumption (MWh) & Heat energy consumption (MWh) & Total energy consumption (MWh) \\
\hline \hline $4,870.9$ & $68,184.1$ & $73,055.0$ \\
\hline
\end{tabular}

In both communes, a survey was conducted among their residents in order to estimate the total consumption of electricity and thermal energy. ${ }^{5}$ The study in Kiszkowo was more detailed as it also included the analysis of the use of different fuels in the process of thermal energy generation in individual households.

The research was conducted in the form of direct interviews with the application of paper and pen personal interview (PAPI). Additionally, in selected cases, we used the in-depth interview method in order to obtain detailed information about the respondents' preferences. The questionnaire included questions concerning:

1. household (floor area, number of residents, location, heating installation),

2. energy consumption (frequency and value of electricity/ heating bills, amount of internally-generated energy),

3. energy sources used (type of electric/thermal energy, with particular emphasis on renewable sources),

4. possibility and readiness to produce and/or use energy from renewable sources, (real and potential supply of energy from renewable sources, one's beliefs in this respect and one's knowledge of this area).

As regards people who declared their willingness to use home renewable energy installations or who already have such at their homes, the in-depth interview specified information concerning the type of installations, their actual/expected capacity/efficiency and the opinion of users about their drawbacks and benefits.

The survey conducted in Barwice was of a basic character and was used for preparing the Low Carbon Emission Plan

5 The sampling was not random, although about $10 \%$ of the Kiszkowo commune's residents took part in the survey (521 questionnaires), which justifies some generalizations of the results. for the Commune of Barwice. The data was obtained with the application of the "bottom-up" method - collecting it at source, mainly through field inventory - and the "top-down" method - obtaining aggregated data for a larger unit, area or population (Low Carbon Emission Plan..., 2016).

On the basis of the obtained data, the total annual consumption of energy in each commune was estimated (Tables 2-4).

The obtained data show differences concerning the declared use of thermal and electric energy in both units. The consumption of electricity changes proportionally to a change in the size of population in the communes under study, but the consumption of thermal energy does not display a similar relationship. Referring it to the number of inhabitants, it is much bigger per capita in Barwice.

It should also be pointed out here that publicly available data in Poland do not provide information about the consumption of electric and thermal energy aggregated on the level of communes. As a result, each time detailed data have to be obtained through a field study or estimated on the basis of average data adjusted locally. What is the implication of the above is the wide differentiation of available information as regards demand for energy and its actual consumption. At the same time, any minor contributions in this area, whether they are part of scientific research or concern the preparation of strategic documents in communes, are valuable, because they give us a rough idea of the actual energy balance of a commune.

Possibilities of satisfying the energy needs of rural community residents with renewable energy sources the maximum and real scenario

There are a lot more differences in the area of research into the possibilities of satisfying the energy needs of rural community residents, including satisfying them with 
Table 5 The percentage of energy produced from different sources in the energy balance of the commune

\begin{tabular}{|c|c|c|c|c|c|}
\hline \multirow[t]{2}{*}{ Commune } & \multirow{2}{*}{$\begin{array}{l}\text { Total amount of } \\
\text { energy consumed in } \\
\text { the commune (kWh) }\end{array}$} & \multicolumn{4}{|c|}{$\begin{array}{l}\text { Percentage of energy produced from different sources in the energy balance of the } \\
\text { commune (\%) }\end{array}$} \\
\hline & & biomass combustion & wind power & solar power & all sources \\
\hline \multicolumn{6}{|c|}{ Real scenario } \\
\hline Kiszkowo & 17412 & 2.73 & 1.2 & 25.3 & 29 \\
\hline \multicolumn{6}{|c|}{ Maximum scenario } \\
\hline Barwice & $73,055.0$ & 141 & 94 & 38 & 273 \\
\hline
\end{tabular}

the exclusive use of renewable sources. In the analyzed case of the communes of Kiszkowo and Barwice, we present calculations concerning the possibility of meeting the demand for thermal energy and electricity with the application of two different approaches. The first of them involves the maximization of the use of the available sources of renewable energy. Taking into consideration the wind and solar conditions in a given area, having examined the state of land use in the context of possible locations for wind power plants and having thoroughly analyzed the use of other energy sources (including the energy obtained from biomass combustion with reference to business/agricultural activity conducted on a given territory), we estimated possibilities regarding the satisfaction of the commune's energy needs with renewable sources in the best possible way. In the other approach, the maximum estimates were adjusted by taking into account the society's readiness to generate and consume energy from renewable sources. This readiness was identified on the basis of a social survey. Each time we also took account of the climatic and spatial conditions specific to a given commune and its formal and legal limitations (for example, those related to area or species protection). As a result, we gathered information about the amount of energy obtained from different energy sources that a commune was able to generate. By referring these values to the residents' demand for energy (thermal and electric) defined before, we came up with the potential supply of energy in relation to demand expressed in percentage (Table 5). The table presents extreme values for both scenarios. The maximum possibilities for the commune of Barwice were three times bigger than the commune's demand for energy. The total annual consumption of energy from renewable sources may amount to over $236,000 \mathrm{MWh}$. This scenario also assumes that solar panels will be installed on the roofs of houses and wind power plants will be located in all places where it is legally and spatially acceptable, and that the obtained biomass will be fully utilized. ${ }^{6}$

In the real scenario made for the commune of Kiszkowo, our calculations were first of all based on the results of the social survey, in which the interviewees were asked whether they would be ready to install sources of renewable energy and use them. The respondents generally showed very little acceptance for this type of investments. Less than $5 \%$ of them were willing to use renewable energy sources. What they found the main barrier were financial limitations, but they also expressed their doubts concerning the cost-

6 In the units under study, it is not possible to use renewable energy from geothermal sources or hydropower. effectiveness of such investments, the risks they entail, and their limited efficiency.

\section{Conclusions}

Given the above research results, despite spatial, environmental and legal limitations, it is possible to satisfy the energy needs of rural community residents from renewable sources.

The main obstacles to the implementation of such solutions are of an economic and social character. What is more, which was not the subject of our analysis, but is emphasized in the existing body of literature (e.g. in the work by Peeters and Schomerus), the key role in changing the structure of the energy balance of communes is played by local governments (Peeters and Schomerus, 2014, et seq.). Their activity should refer not only to the issue of the shaping of spatial policy (Bazan-Krzywoszańska et al., 2016), but also to supporting the economic possibilities and social acceptance of such solutions. The lack of knowledge on renewable sources, changes in the related legal regulations concerning them, and insufficient financial stimuli for individual households contribute to the fact that renewable energy sources may generate the supply of energy only to a limited degree. The above examples also show that in-depth social surveys, which verify the theoretical assumptions of diagnoses and scenarios, are extremely important for estimating demand for energy and identifying possibilities of generating it in a given area.

\section{References}

BAÑOS, R. - MANZANO-AGUGLIARO, F. - MONTOYA, F.G. - GIL, C. ALCAYDE, A. - GÓMEZ, J. 2011. Optimization methods applied to renewable and sustainable energy: A review. In Renewable and Sustainable Energy Reviews, vol. 15, no. 4, pp. 1753-1766. doi. org/10.1016/j.rser.2010.12.008.

BAZAN-KRZYWOSZAŃSKA, A. - MRÓWCZYŃSKA, M. - SKIBA, M. - ŁACZAK, M. 2016. Economic conditions for the development of energy efficient civil engineering using RES in the policy of cohesion of the European Union (2014-2020). Case study: The town of Zielona Góra. In Energy and Buildings, no. 118, pp. 170-180.

CLAPP, C. - BRINER, G. - KAROUSAKIS, K. 2010. Low-Emission Development Strategies (LEDS): Technical, Institutional and Policy Lessons, OECD/IEA Climate Change Expert Group Papers, No. 2010/02, OECD Publishing, Paris. [online] Available at: http://dx.doi. org/10.1787/5k451mzrnt37-en

DIRECTIVE 2009/28/EC of the European Parliament and of the Council of 23 April 2009 on the promotion of the use of energy from renewable sources and amending and subsequently repealing 
Directives 2001/77/EC and 2003/30/EC. In Official Journal of the European Union L 140 of 5 June 2009, p. 16, as amended.

DIRECTIVE 2012/27/EU of the European Parliament and of the Council of 25 October 2012 on energy efficiency, amending Directives 2009/125/EC and 2010/30/EU and repealing Directives 2004/8/EC and 2006/32/EC. In Official Journal of the European Union L 135 of 14 November 2012, p. 1.

GRACZYK, A. 2016. Koordynacja polityki energetycznej-regionalne ujęcie wsparcia odnawialnych źródeł energii w świetle Strategii rozwoju energetyki na Dolnym Śląsku. In Barometr Regionalny, vol. 14, no. 4, pp. 113-120.

GRADZIUK, P. - GRADZIUK, B. 2016. Low-carbon economy - a new challenge for rural comunes. In Wieś i Rolnictwo, no. 170/1, pp. 105-126.

IMPLEMENTACJA prawa klimatyczno-energetycznego UE W Polsce. Warszawa : Fundacja Client Earth Poland, 2013. ISBN 97883-938296-0-6. [online] Available at: http://www.clientearth.org/ reports/implementacja-prawa-klimatyczno-energetycznego-uew-polsce.pdf

KLOJZY-KARCZMARCZYK B. - MAZUREK, J. 2009. Local government responsibilities in the process of reducting low emission. In Polityka energetyczna, vol. 12, no. 2/2, pp. 277-284.

MINISTRY OF ECONOMY. 2011. Energy Mix 2050. Scenario analysis for Poland. Warsaw.

NATIONAL Action Plan on Renewable Energy. December 7, 2010.

PASKA, J. - SURMA, T. 2014. Electricity generation from renewable energy sources in Poland. In Renewable Energy, vol. 71, pp. 286294. doi.org/10.1016/j.renene.2014.05.011.

PEETERS, M. - SCHOMERUS, T. 2014. Renewable Energy Law in the EU. Edward Elgar Publishing.
PIRIA, R. (red.). 2014. Zazieleniając węglowe serce Europy. Wnioski z czesko-niemiecko-polskiego dialogu wokół energetyki. Raport zlecony i opublikowany przez Fundację im. Heinricha Bölla. [Online] Available at: http://pl.boell.org/sites/default/files/zazieleniajac weglowe_serce_europy_1.pdf

POGGI, F. - FIRMINO, A. - AMADO, M. 2017. SMART RURAL: a model for planning net-zero Energy balance at municipal level. In Energy Procedia, no. 122, pp. 56-61.

POLAND. Energy Law, on Journal of Laws 2017, item 220, as amended.

POLAND. Law Act on energy efficiency of 20 May 2016, on Journal of Laws 2016, item 831.

POLAND. Law Act on renewable energy sources of 20 February 2015, on Journal of Laws 2017, item 1148, as amended.

POLAND. Plan Gospodarki Niskoemisyjnej dla Gminy Barwice (Low Carbon Emission Plan for the commune of Barwice). 2016. Barwice. POLAND. The Energy Mix for Poland until 2060. Warsaw 2013 (The Prime Minister Office, Strategic Analysis Department: The Optimum).

POLAND. The Polish Energy Policy until 2030 (November 10, 2009). POLAND. The strategy of "Energy Security and Environment perspective until 2020" adopted by the Council of Ministers.

ŚLIŻ-SZKLINIARZ, B. 2013. Energy Planning in Selected European Regions - Methods for Evaluating the Potential of Renewable Energy Sources. Karlsruhe : Karlsruher Institut für Technologie.

SZCZERBOWSKI, R. - CERAN B. 2015. Transformation of Polish Energy Policy in the Context of Changes in European Union Member States. In Acta Energetica, vol. 3, no. 24, pp. 108-113. DOI: 10.12736/issn.2300-3022.2015310. 